\title{
An emerging right to care in the EU: a "New Start to Support Work-Life Balance for Parents and Carers"
}

\author{
Eugenia Caracciolo di Torella ${ }^{1}$
}

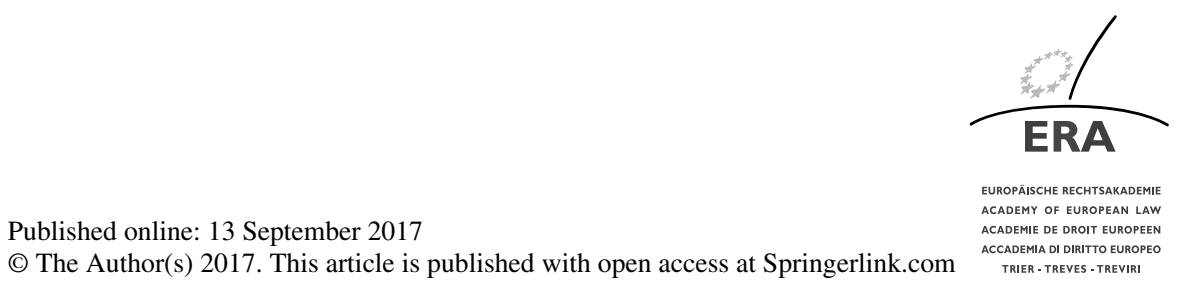

Abstract Reconciliation between work and family life has been a prominent feature of EU discourse, policy and legislation for some time now. Accordingly, an increasingly sophisticated array of measures has been implemented. This article focuses on the most recent EU initiative, namely the New Start to Support Work-Life Balance for Parents and Carers, which was announced on 26 April 2017. It entails a mixture of legislative and non-legislative measures aimed at modernising the regulation of this area. This article maintains that the New Start Initiative, although not flawless, is ground-breaking. In this proposal, the Commission is embracing a substantive and transformative approach to equality. The New Start Initiative has the potential to reconceptualise this area and to move from care as a mother-child issue to a wider one that sees care as an integral part of society.

Keywords Work-life balance $\cdot$ Equality $\cdot$ Caring responsibilities $\cdot$ Brexit

\section{Introduction}

The reconciliation of work and family life has been on the agenda of the European Union (EU) since 1974. ${ }^{1}$ Over the years, EU legislators and policymakers have

\footnotetext{
${ }^{1}$ Council Resolution of 21 January 1974 Concerning a Social Action Programme [1974] OJ C 1/13. See in general (2015) 37:3 Journal of Social Welfare and Family Law: A Special Issue on Reconciliation of Work and Family Life.
}

I am indebted to all the participants to the Conference Rethinking Gender Equality, in particular S. Feenstra, London 19 May 2017 for the lively discussion and to A. Masselot, S. Burri and R. Sattar for comments on earlier versions. Any errors are my sole responsibility.

$凶$ E. Caracciolo di Torella ecdt1@1eicester.ac.uk

1 University of Leicester, Leicester, UK 
striven to develop a framework to help working parents to balance their working and caring responsibilities and a range of policy and legislative ${ }^{2}$ measures have gradually been adopted. This framework has been a driving force in this area and has triggered the development of national legislation. There is little doubt that, without it, working parents across Europe would not be in the position they are today. Yet, evidence shows that significant obstacles still exist. On the one hand, women across Europe continue to shoulder the lion's share of caring responsibilities and, consequently, continue to be underrepresented in the labour market. ${ }^{3}$ This affects their present and future attachment to the employment market thus heightening the risk of poverty and social exclusion. ${ }^{4}$ On the other hand, men cannot always avail themselves of their parental rights. ${ }^{5}$ Ultimately, children are affected. ${ }^{6}$ Furthermore, caring responsibilities outside childcare are still barely mentioned. ${ }^{7}$ This presents issues of fairness, gender equality, optimal allocation of skills, fiscal sustainability and poverty. Addressing this is, today more than ever, both a social and economic imperative.

On 26 April 2017, as part of the European Pillar of Social Rights, ${ }^{8}$ the European Commission announced a specific set of measures to modernise the current framework, namely the "New Start to Support Work-Life Balance for Parents and Carers" (the New Start Initiative). ${ }^{9}$ This is a very ambitious project that builds upon the existing acquis in this area and aims to modernise the existing framework which was set up in the 1990s. This article offers a first insight on the initiative and is organised into two main parts. The first part explains to the reader the background, the context and the aim of the New Start Initiative. The second part focuses on its content, namely the proposed legislative and non-legislative measures, as well as what is not included, in particular a revision of the Pregnant Workers Directive. In light of this discussion, this article concludes that, although the New Start Initiative remains incomplete, it is also bold and innovative; to date, is the most comprehensive proposal in this area. Furthermore, the latest political developments in the EU suggest that this initiative stands a good chance of being successful.

\footnotetext{
${ }^{2}$ In particular Directive 2006/54/EC on the implementation of the principle of equal opportunities and equal treatment of men and women in matters of employment and occupation (recast) [2006] OJ L 204/23; Council Directive 2010/18/EU implementing the revised Framework Agreement on parental leave concluded by Business Europe, UEAPME, CEEP and ETUC and repealing Directive 96/34/EC [2010] OJ L 68/13; Council Directive 92/85/EEC on the introduction of measures to encourage improvements in the safety and health at work of pregnant workers and workers who have recently given birth or are breastfeeding; Council Directive 97/81/EC of 15 December 1997 concerning the Framework Agreement on part-time work concluded by UNICE, CEEP and the ETUC [1998] OJ L 14/9.

${ }^{3}$ Eurofund [9].

${ }^{4}$ Masselot/Caracciolo di Torell/Burri [14].

${ }^{5}$ See for example Case C-5/12 Betriu Montull, EU:C:2013:571. More generally see Fredman [12]; Caracciolo di Torella [5, 6]; Caracciolo di Torella [7]; Burri [1].

${ }^{6}$ European Commission Recommendation, Investing in children: breaking the cycle of disadvantage, 20 February 2013, [2013] OJ L 59/5; see also Masselot [15].

${ }^{7}$ Horton [13].

${ }^{8}$ Available at https://ec.europa.eu/commission/priorities/deeper-and-fairer-economic-and-monetary-union/ european-pillar-social-rights_en (as of 23 June 2017) (as of 23 June 2017).

${ }^{9}$ Available at https://ec.europa.eu/info/law/better-regulation/initiatives/com-2017-253_en (as of 23 June 2017).
} 


\section{The New Start Initiative: background and aim}

It is not the first time that the EU has attempted to address this area and it is not the purpose of this article to provide an historical review. ${ }^{10}$ In this context, suffice to say that in 2008 the European Commission put forward the Work-Life Balance Package ${ }^{11}$ consisting of a set of measures aimed at helping working parents. It included a Communication from the European Commission ${ }^{12}$ explaining the background and context, a report monitoring national progress towards the Barcelona childcare targets ${ }^{13}$ and two legislative proposals to revise existing directives, namely the Self-employed Workers Directive ${ }^{14}$ and the Pregnant Workers Directive. ${ }^{15}$ Whilst the former was successfully adopted, ${ }^{16}$ the latter encountered considerable opposition, most notably by the UK, and for years has been blocked in the Council. Attempts to provide a comprehensive solution failed and eventually it was withdrawn in July $2015 .{ }^{17}$ In the same year, the Commission announced the Roadmap "New Start to address the Challenges of Work-life Balance faced by Working Parents" 18 where the case for further action in this area was again put forward. As required by Article 154 TFEU, a two-phase consultation with the Social Partners followed. The first consultation on the direction of Union's action took place between 11 November 2015 and 4 January 2016 and the second, on the content of the envisaged proposal, took place between 18 November 2015 and 17 February 2016. Following the consultations, the New Start Initiative was introduced as part of the European Pillar of Social Rights. ${ }^{19}$ This is based on 20 principles, three of which are particularly relevant to understanding the

\footnotetext{
${ }^{10}$ See generally, McGlynn [16]; Caracciolo di Torella/Masselot [5].

${ }^{11}$ See MEMO/08/603, 3 October 2008, available at http://europa.eu/rapid/press-release_MEMO-08-603_ en.htm (as of 23 June 2017); see also Commission Improves Work-Life Balance for Millions with Longer and Better Maternity Leave, Brussels 3 October 2008 IP/08/1450 available at http://europa.eu/ rapid/press-release_IP-08-1450_en.htm (as of 23 June 2017).

${ }^{12}$ Communication from the Commission, A Better Work Life Balance: Stronger Support for Reconciling Professional, Private and Family Life, COM (2008) 635.

${ }^{13}$ European Commission Report, Implementation of the Barcelona Objectives Concerning Facilities for Pre-School-Age Children, COM (2008) 638.

${ }^{14}$ Proposal for a Directive on the application of the principle of equal treatment between men and women engaged in an activity in a self-employed capacity and repealing Directive 86/613/EEC, COM (2008) 636.

${ }^{15}$ Proposal for a Directive amending Council Directive 92/85/EEC on the introduction of measures to encourage improvements in the safety and health at work of pregnant workers and workers who have recently given birth or are breastfeeding, COM (2008) 637 final-2008/ 0193 (COD).

${ }^{16}$ Directive 2010/41/EU of the European Parliament and of the Council on the application of the principle of equal treatment between men and women engaged in an activity in a self-employed capacity and repealing Directive 86/613 [2010] OJ L 180/1.

${ }^{17}$ European Commission, "Delivering for parents: Commission withdraws stalled maternity leave proposal and paves the way for a fresh approach", Brussels, 1 July 2015 (http://europa.eu/rapid/pressrelease_IP-15-5287_en.htm).

${ }^{18}$ Available at http://ec.europa.eu/smart-regulation/roadmaps/docs/2015_just_xxx_maternity_leave.en.pdf.

${ }^{19}$ Available at https://ec.europa.eu/commission/priorities/deeper-and-fairer-economic-and-monetaryunion/european-pillar-social-rights_en (as of 23 June 2017).
} 
context of this initiative. These are Principle 2 on Gender Equality, ${ }^{20}$ Principle 3 on Equal Opportunities, ${ }^{21}$ and Principle 9 on Work-life Balance. The latter states that "[p]arents and people with caring responsibilities have the right to suitable leave, flexible working arrangements and access to care services. Women and men shall have equal access to special leaves of absence in order to fulfil their caring responsibilities and be encouraged to use them in a balanced way."

Thus the New Start Initiative is the result of an emerging approach in which the Commission places individuals at the heart of its policies. It is a very ambitious project which aims to: set up a modern policy framework that seeks to increase female participation in the labour market and reduce the gender pay gap; provide workers, in particular men, with more opportunities and choice to balance their professional and caring responsibilities; support Member States' modern family policies and address demographic and societal challenges. ${ }^{22}$

To achieve these aims, it is formed by a mix of mutually-reinforcing legislative and non-legislative measures. Although it acknowledges that legislative intervention is crucial, the initiative accepts that it is equally important to leave room for national and local diversity and allow Member States to make reforms of different kinds to suit their particular situation. This will also ensure that the measures are not introduced in a top-down fashion. Overall, even if the New Start Initiative builds upon the existing acquis in this area, namely maternity, paternity and parental leave and flexible working arrangements, it is nevertheless innovative. Its value is in the very fact that, by linking all these measures and presenting a coordinated approach, it provides the opportunity to reconceptualise work-life balance. The following sections will explore the measures in detail.

\section{The proposed measures}

\subsection{The legislative measures}

The New Start Initiative proposes nothing less than a Directive on Work Life Balance for Parents and Carers. ${ }^{23}$ This Directive does not affect the rights contained in the Pregnant Workers Directive, which remain intact, but rather aims to strengthen and build upon them. The proposed Directive, based on Article 153 TFEU, ${ }^{24}$ repeals the

\footnotetext{
20 "Equality of treatment and opportunities between women and men must be ensured and fostered in all areas, including regarding participation in the labour market, terms and conditions of employment and career progression. Women and men have the right to equal pay for work of equal value."

21 "Regardless of gender, racial or ethnic origin, religion or belief, disability, age or sexual orientation, everyone has the right to equal treatment and opportunities regarding employment, social protection, education, and access to goods and services available to the public. Equal opportunities of under-represented groups shall be fostered."

${ }^{22}$ Communication from the Commission, An Initiative to support Work-life Balance for Working Parents and Carers, COM (2017) 252 final, available at https://www.eerstekamer.nl/bijlage/20170502/ com_2017_252_commissiemededeling/document3/f=/vkdvedys2dxw.pdf (as of 23 June 2017).

${ }^{23}$ Proposal for a Directive on the EU Parliament and the Council on Work-Life Balance for Parents and Carers COM (2017) 253 final, 2017/0085 (COD).

${ }^{24}$ More precisely:
} 
Parental Leave Directive. ${ }^{25}$ It applies to all workers, men and women who have an employment contract or an employment relationship ${ }^{26}$ and provides for four individual rights.

Firstly, it strengthens the right to parental leave. ${ }^{27}$ The current legislation has proven ineffective in promoting the use of this right, especially when it comes to fathers. ${ }^{28}$ Two main reasons for the low uptake have been identified: the entitlement is unpaid, therefore not many families can afford to take it; and the implementation is inflexible which, de facto, can have the effect of "forcing" people ${ }^{29}$ to take the leave in blocks, rather than in more flexible ways (part-time or in individual days) that may better suit their needs. This means that, when taken, it is often by mothers thus reinforcing the stereotype that women, rather than men, are carers. By way of contrast, the proposed Directive aims to make it easier for men to share caring responsibilities on an equal basis with women ${ }^{30}$ and for this purpose it establishes that the 4-month period, available to each parent, is non-transferable from a parent to another. ${ }^{31}$ Crucially it also establishes that the leave should receive an adequate income at least equivalent to sick pay level. ${ }^{32}$ Finally, the maximum age of the child for whom parents can take leave is increased from 8 to 12 years old, thus expanding the pool of people who can apply for the leave.

Secondly, it introduces an individual right to paternity leave, ${ }^{33}$ intended as a short period of leave for fathers around the time of the birth of a child. This is not particularly controversial as the vast majority of the Member States already have paternity leave provisions. ${ }^{34}$ At EU level, paternity leave was first put forward in the Work-Life

Art. 153(1) TFEU "With a view to achieving the objectives of Article 151, the Union shall support and complement the activities of the Member States in the following fields: (...)

(i) equality between men and women with regard to labour market opportunities and treatment at work;" Art. 153(2)(b) TFEU establishes that "to this end, the European Parliament and the Council: (...)

(b) may adopt, in the fields referred to in paragraph 1(a) to (i), by means of directives, minimum requirements for gradual implementation, having regard to the conditions and technical rules obtaining in each of the Member States. Such directives shall avoid imposing administrative, financial and legal constraints in a way which would hold back the creation and development of small and medium-sized undertakings.

The European Parliament and the Council shall act in accordance with the ordinary legislative procedure after consulting the Economic and Social Committee and the Committee of the Regions. (...)".

${ }^{25}$ Art. 19, proposed Directive on Work-Life Balance for Parents and Carers.

${ }^{26}$ Art. 2, proposed Directive on Work-Life Balance for Parents and Carers.

${ }^{27}$ Art. 5, proposed Directive on Work-Life Balance for Parents and Carers.

${ }^{28}$ Eurofund [10], 2015.

${ }^{29}$ There is evidence that this is more an issue for fathers. See Eurofund [10].

${ }^{30}$ Proposal for a Directive on the EU Parliament and the Council on Work-Life Balance for Parents and Carers COM (2017) 253 final, Preamble, Recital 5, see also Recitals 14 and 15.

${ }^{31}$ Art. 5(2), proposed Directive on Work-Life Balance for Parents and Carers, see also Recital 14 in the Preamble.

${ }^{32}$ Art. 8, proposed Directive on Work-Life Balance for Parents and Carers.

${ }^{33}$ Art. 4, proposed Directive on Work-Life Balance for Parents and Carers.

${ }^{34}$ However they do not always work in practice. See also A quarter of new dads are missing out on paternity leave and pay, says TUC https://www.tuc.org.uk/node/127022 (as for 23 June 2017). 
Balance package in $2008^{35}$ and the suggestion had been incorporated by the Parliament in the proposal to amend the Pregnant Workers Directive. The Progress report, however, highlighted that even if the Directive had been amended, there was a consensus that paternity leave would not have been included. ${ }^{36}$ At the time of writing, the EU has no express rules in this area, apart from the amended Equal Treatment Directive $^{37}$ and the Recast Directive. ${ }^{38}$ These instruments acknowledge fathers in their own right but do not confer specific rights on them. Article 2(7) of the Amended Equal Treatment Directive states that "it is (...) without prejudice to the right of Member States to recognise distinct rights to paternity and/or adoption leave." Article 16 of the Recast Directive concerns paternity and adoption leave and confirms the provisions of the amended Equal Treatment Directive for fathers in approximately the same terms. ${ }^{39}$ Therefore these instruments, rather than granting positive rights to fathers, merely provide that the same level of protection as applies to maternity leave must be extended to paternity and adoption leave, if Member States have already introduced such rules into national law. As a result, fathers' rights have been construed as an option for Member States to consider, rather than as individual rights. ${ }^{40}$

Thus the proposed Directive is a welcome improvement. The right is not only for fathers but also for second parents and is granted irrespective of marital or family status as defined in national law. ${ }^{41}$ Member States must ensure that they shall have the right to take at least 10 working days of leave around the time of birth of a child. In this case, the leave will also be compensated at least at the level of sick pay. ${ }^{42}$ This is a much stronger commitment than the one envisaged at the moment which would bring EU legislation in line not only with the legislation already existing in the Member States but also with case law of the European Court of Justice ${ }^{43}$ and a rapidly changing society.

${ }^{35}$ Consultation Document SEC (2006) 1245 and SEC (2008) 571 as discussed in the Communication from the Commission, "A Better Work-Life Balance: stronger support for reconciling professional, private and family Life", COM (2008) 635. See also European Commission, Employment, Social Affairs and Equal Opportunities, "Opinion on New Forms of Leave (Paternity Leave, Adoption Leave and Filial Leave)", 2008.

${ }^{36}$ The EU Council, Proposal, Progress Report, 2008/0193 (COD) SOC 423/SAN 107/CODEC 875.

${ }^{37}$ Council Directive 76/207/EEC [1976] OJ L 39/40 as amended by Directive 2002/73/EC [2002] OJ L $269 / 15$.

${ }^{38}$ Directive 2006/54/EC of the European Parliament and of the Council of 5th July 2006 on the implementation of the principle of equal opportunities and equal treatment of men and women in matters of employment and occupation (recast) [2006] OJ L/204.

39،"This Directive is without prejudice to the right of Member States to recognise distinct rights to paternity and/or adoption leave. Those Member States which recognise such rights shall take the necessary measures to protect working men and women against dismissal due to exercising those rights and ensure that, at the end of such leave, they are entitled to return to their jobs or to equivalent posts on terms and conditions which are no less favourable to them, and to benefit from any improvement in working conditions to which they would have been entitled during their absence."

${ }^{40}$ See Recital 13 in the Preamble and Article 2(7) of the Directive 76/207 as amended by Directive 2002/73.

${ }^{41}$ Art. 4, proposed Directive on Work-Life Balance for Parents and Carers.

${ }^{42}$ Art. 8, proposed Directive on Work-Life Balance for Parents and Carers.

${ }^{43}$ Case C-222/14 K. Mä̈strellis v Ypourgos Dikaiosynis, Diafaneias kai Anthropinon Dikaiomaton, EU:C:2015:473; see also the Opinion of AG Kokott in Case C-104/09 Roca Álvarez v Sesa Start España ETT SA, EU:C:2010:254. 
Thirdly, the proposed Directive introduces provisions for carers' leave, intended as "a worker providing personal care or support in case of a serious illness or dependency of a relative." 44 This grants working carers at least five working days per year in the event of serious illness or dependency of a relative. Needless to say, it is a significant improvement: at the moment EU legislation does not cater for the needs of working carers. This is a cause of concern as it has a clear effect on women's participation in the employment market. The closest the current legislation gets to carers" leave is the leave for "force majeure" 45 which provides that workers can take unpaid time off for workers caring for seriously ill or dependent relatives. Although this is the only truly family - rather than just child - friendly provision, it is a right to take time off to (swiftly) address emergencies rather than a right to care. Article 6 of the proposed directive, prima facie, builds on this provision and grants working carers the right to take at least five days per year, compensated at least at sick pay level. Whilst, conceptually, this is an unprecedented initiative that acknowledges care as an integral part of life and thus accepts that working carers have needs, in practice it is not enough to allow those who have on-going caring responsibilities to care on a regular basis. Rather than developing a much needed care strategy, this provision merely strengthens the existing "safety net" for emergencies.

The final legislative measure grants parents and carers the possibility to work flexibly to adapt their working schedules to their personal needs and preferences so that they can better balance their work and caring responsibilities. This will involve either changing and or reducing their working hours or their place of work (e.g. teleworking). ${ }^{46}$ There is a wealth of evidence suggesting that this is crucial to allow individuals (in particular women) to remain in the workplace. It is true that this is perhaps the least innovative of the measures as general legislation that protects workers on part-time contracts already exists. ${ }^{47}$ Furthermore, at the moment, parents returning from parental leave are explicitly allowed to request flexible working arrangements for a set period of time. ${ }^{48}$ With that said, it is the first time that flexible forms of employment are expressly linked to the broader concept of caring responsibilities.

However, the proposed legislation does not go far enough to create a strong and enforceable legal entitlement. The right remains framed as a right to request, rather than a right to obtain where employers are obliged to merely consider and respond to such requests, taking into account the needs of both employers and workers. Furthermore, Zbyszewska $^{49}$ notes that there is no reference to the main instrument in this area,

\footnotetext{
${ }^{44}$ Art. 6, proposed Directive on Work-Life Balance for Parents and Carers.

${ }^{45}$ Already contemplated by clause 7(1) Directive 2010/18/EU on Parental Leave ([2010] OJ L 68/13) and in Art. 7 of the proposed Directive.

${ }^{46}$ Art. 9, proposed Directive on Work-Life Balance for Parents and Carers.

${ }^{47}$ See e.g. Council Directive 1999/70/EC of 28 June 1999 concerning the framework agreement on fixedterm work concluded by ETUC, UNICE and CEEP [1999] OJ L 175/43; corrigendum in [1999] OJ L $244 / 64$.

${ }^{48}$ See Clause 6, Council Directive 97/81/EC, concerning the Framework Agreement on part-time work concluded by UNICE, CEEP and the ETUC [1998] OJ L 14/9.
}

${ }^{49}$ Zbyszewska [18]. 
namely the Working Time Directive. ${ }^{50}$ Although this is a health and safety-rather than a gender equality -instrument, it is the key EU instrument regulating "normal" working hours, where "normal" continues to be based on "male" patterns, as men are more likely than women to engage in full-time work and/or work in excess of "normal" working hours. Thus, she convincingly argues that, as working excessive hours interferes with the assumption of caring responsibilities, it is in this context that changes are needed, in particular if the goal is to encourage men to take a more active role in care and to enable women's better access to paid employment.

Overall, the rights proposed are, to some extent, incomplete and certainly require further elaboration. Although they strive to address the needs of an ageing society, they continue to privilege parents of young children. Furthermore, although workers are protected against discrimination for using these rights, ${ }^{51}$ a wider protection not to be discriminated against because of caring responsibilities still does not exist. ${ }^{52}$ Despite this, the potential of the proposed Directive is unquestionable: it creates concrete individual rights and sends a powerful message. Caring responsibilities have now explicitly been placed on the EU agenda.

\subsection{A noticeable absentee: the Pregnant Workers Directive}

Just as important as what the Directive includes is what it does not include. It is paradoxical and disappointing that the content of the Pregnant Workers Directive was not revised. It is paradoxical because the New Start Initiative was de facto triggered by the very failure to revise this Directive. It is disappointing because this feels like a missed opportunity. Indeed, it had been suggested that the withdrawal of the proposed revision could have paved the way to the introduction of a more progressive framework. ${ }^{53}$ A revised Pregnant Workers Directive could have included situations that, due to medical advancements, are becoming increasingly common, ${ }^{54}$ namely IVF and surrogacy. ${ }^{55} \mathrm{~A}$ clarification by the EU legislature on, for example, the rights of commissioning mothers, would have been welcomed. This is particularly regrettable, in light of the fact that some Member States have already introduced some rights in this respect. ${ }^{56}$ The Commission itself had announced that " $[t]$ his opens the way for a fresh approach to the policy objectives of improving the protection of mothers ...". 57

${ }^{50}$ Council Directive 93/104 EC concerning certain aspects of the organization of working time [1993] OJ L 307/18 (repealed); Council Directive 2003/88 EC of the European Parliament and of the Council of 4 November 2003 concerning certain aspects of the organization of working time [2003] OJ L 299/9.

${ }^{51}$ Art. 11 proposed Directive on Work-Life Balance for Parents and Carers.

${ }^{52}$ See further, Caracciolo di Torella [8].

${ }^{53}$ Caracciolo di Torella/Foubert [4].

${ }^{54}$ European Parliament, "A Comparative Study on the Regime of Surrogacy in EU Member States" (Publications Office of the EU, 2013), p. 9, http://www.europarl.europa.eu/RegData/etudes/ STUD/2013/474403/IPOL-JURI_ET(2013)474403_EN.pdf (accessed 23 June 2017). See also Trimmings/Beaumont [17].

${ }^{55}$ Caracciolo di Torella/Foubert [3]. Foubert/Imamović [11].

${ }^{56}$ From April 2015 the Children and Families Act 2014 grants to intended parents in surrogacy arrangements qualify for adoption leave and pay.

${ }^{57}$ European Commission, "Delivering for Parents: Commission withdraws stalled maternity leave proposal and paves the way for a fresh approach" Press release, 1 July 2015, http://europa.eu/rapid/ 
It is understandable that the very same amendments, in particular the longer period of maternity leave and the enhanced level of payment, that had caused the failure of the proposal in 2015, could not have been re-proposed. Measures to strengthen the position of women workers could have been introduced, however. Indeed improving dismissal protection ${ }^{58}$ and introducing further provisions for breastfeeding breaks and/or facilities ${ }^{59}$ had originally been suggested. Both types of measures would have eased the transition back to work after maternity leave.

\subsection{The non-legislative measures}

In addition to the measures discussed above, the Commission has proposed a set of non-legislative measures aimed at creating a policy framework to enhance the effectiveness, for both women and men, of the rights envisaged in the Work-Life Balance Directive. ${ }^{60}$ Arguably, policy initiatives at EU level are already in place. ${ }^{61}$ However, they are often fragmented and not complementary to the existing legislation. For example, the system of leave is not developed in conjunction with affordable childcare services and this, de facto, limits the choice of working parents (often mothers) and weakens their protection. In many cases, it simply delays the moment when women will leave the employment market. Thus the current mismatch between legislation and policy can have the undesired side effect of reinforcing gender inequality. By contrast, the proposed non-legislative initiatives, by specifically addressing these gaps, aim to target the drivers of women's underrepresentation in the labour market in a comprehensive way.

One of the main aims of the non-legislative measures is to enhance the monitoring of the transposition of EU legislation and to pursue the launch of infringement procedures when necessary and to promote compliance through raising awareness. They also aim at improving the data collection of EU-level data by Eurostat on the takeup of family-related leave and flexible working arrangements by women and men. Furthermore, they will promote the sharing of good practices with social partners and Member States by means, for example, of seminars under the Mutual Learning programme.

Finally, the EU endeavours to support the Member States to address the lack of adequate care services for both children and adults through making funding available to

press-release_IP-15-5287_en.htm. See P. Foubert, Child Care Leave 2.0-Suggestions for the improvement of the EU Maternity and Parental Leave Directives from a rights perspective in the Maastricht Journal of European and Comparative Law 2017, Vol. 24(2) pp. 245-263.

${ }^{58}$ This could have been done by extending the period of dismissal protection for a period of time after the end of maternity leave; prohibiting not only dismissals during the protected period but also steps for dismissal, such as recruiting a replacement employee on a permanent base; introducing a right to written reasons for dismissals during the full period for which dismissal protection is available.

${ }^{59}$ Breastfeeding facilities are instead addressed under the non-legislative measures (see discussion above in this article).

${ }^{60}$ Communication from the Commission, An Initiative to support Work-life Balance for Working Parents and Carers, COM (2017) 252 final.

${ }^{61}$ See for example Council Recommendation 92/241 EEC on childcare [1992] OJ L 123/16 and more recently, Council Recommendation 2013/112 EU Investing in Children: Breaking the circle of disadvantage [2013] OJ L 59/5. 
develop child and long term care. Funding will also be available under the Programme for Employment and Social Innovation ${ }^{62}$ that will fund new pilot schemes addressed to employers for the development of innovative working arrangements such as family leaves and flexible working arrangements. The importance of the non-legislative measures cannot be emphasised enough. By raising awareness and sharing best practice, they contribute to shaping an environment where care is seen as an integral and unavoidable part of society. Potentially, they are more far reaching than the legislative measures.

\section{Conclusions}

The New Start Initiative is a step in the right direction that must be commended and celebrated. This is not to say that it is flawless. For example, whilst the system of leave provided by the Directive is supported by a prohibition on discrimination for using the rights, a general right not to be discriminated against on grounds of caring responsibility is still not provided. Furthermore, the overall legislative measures continue to privilege parents of young (and healthy) children over carers of adults. In addition, the individual rights proposed need to be developed. Despite this, in many respects, the New Start Initiative is ground-breaking. So far, measures in this area have been introduced in a piecemeal fashion, at different stages, with different legal bases and have lacked the underpinning of a clear vision. They have focused on improving the situation of women in the context of paid employment, rather than looking at the effect of unpaid work in general, and caring responsibilities in particular. In other words, they have failed to promote substantive and transformative equality. By contrast, the New Start Initiative presents an integrated approach that will help to reconceptualise the whole area. By doing so, it moves away from the health and safety $v$ equality dichotomy and introduces what commentators have argued for some time, namely a right to care. ${ }^{63}$ Such an integrated approach acknowledges that care is a life-cycle, an on-going commitment that does not end when children go to school. On a more practical level, the integrated approach is important because if policies and legislation are drafted in isolation, they carry the risk of reinforcing gender stereotyping. For example, if any form of child related leave (maternity, paternity or parental) is not complemented by the possibility to introduce flexibility in one's working arrangements, in practice, it might be of very limited help. Equally, if they are not complemented by an expansion of affordable care services, they will merely postpone the point at which a carer (often a woman) will exit the labour market. Furthermore, the New Start Initiative, in particular the Work-Life Balance Directive, will be the first legislative measure that expressly acknowledges that men are pivotal to the success of reconciliation measures.

As a final thought, this article reflects on the chances of the New Start Initiative succeeding. Of course it is not possible to predict with certainty if it will succeed. It might be adopted with significant amendments that would (further) water down its

${ }^{62} \mathrm{http}: / /$ ec.europa.eu/social/main.jsp?catId=1081 (as of 23 June 2017).
${ }^{63}$ See e.g. Busby [2]. 
practical potential. Even with amendments, however, the importance of the principle it embodies will stand. With that said, the European Commission has made clear that its success will require a "shared commitment" and invites the EU political institutions to endorse and to actively support the New Start Initiatives. These institutions are encouraged to work in close cooperation with social partners and all other relevant stakeholders to "step up their efforts in providing better work-life balance policies and allow for improved well-being of our European society". 64 The New Start Initiative in general and the Work-Life Balance Directive in particular, are likely to succeed because this shared commitment is exactly what is happening. Indeed, arguably as a consequence of the Brexit vote, the remaining 27 Member States are now closer than ever. $^{65}$ This might mean that, initiatives such as this, which in the past have encountered the opposition of the $\mathrm{UK},{ }^{66}$ are now more likely to go forward. If Brexit has a silver lining, it is that, ironically, it has potentially created the possibility to achieve a more inclusive and supportive European society.

Open Access This article is distributed under the terms of the Creative Commons Attribution 4.0 International License (http://creativecommons.org/licenses/by/4.0/), which permits unrestricted use, distribution, and reproduction in any medium, provided you give appropriate credit to the original author(s) and the source, provide a link to the Creative Commons license, and indicate if changes were made.

\section{References}

1. Burri, S.: Parents who want to reconcile work and care: which equality under EU law? In: van den Brink, M., Burri, S. Goldschmidt, J. (eds.) Equality and Human Rights: Nothing but Trouble? Liber Amicorum Titia Loenen, pp. 261-277. SIM/Universiteit Utrecht, Utrecht (2015)

2. Busby, N.: A Right to Care? Unpaid Care Work in European Employment Law. Oxford University Press, London (2011)

3. Caracciolo di Torella, E., Foubert, P.: Maternity rights for intended mothers? Surrogacy puts the EU legal framework to the test. Eur. Gend. Equal. Law Rev. 2, 5-11 (2014). https://uhdspace.uhasselt.be/ dspace/bitstream/1942/18509/1/egelr_2014_2_final_web_en.pdf

4. Caracciolo di Torella, E., Foubert, P.: Surrogacy, pregnancy and maternity rights: a missed opportunity for a more coherent regime of parental rights in the EU. Eur. Law Rev. 40(1), 52-69 (2015)

5. Caracciolo di Torella, E., Masselot, A.: Reconciling Work and Family Life in EU Law and Policy (2010). McMillian Palgrave

6. Caracciolo di Torella, E.: Brave new fathers for a brave new world? Fathers as caregivers in an evolving European Union. Eur. Law J. 20(1), 88-106 (2014)

7. Caracciolo di Torella, E.: Men in the work/family reconciliation discourse: the swallows that did not make a summer? J. Soc. Welf. Fam. Law 37(3), 334-344 (2015). A special issue on reconciliation of work and family life

8. Caracciolo di Torella, E.: Shaping and re-shaping the caring relationship in European law: a catalogue of rights for informal carers. Child Fam. Law Q. 28(3) 261-279 (2016)

9. Eurofund: The gender employment gap: challenges and solutions (2016). Available at: https:// www.eurofound.europa.eu/publications/report/2016/labour-market/the-gender-employment-gapchallenges-and-solutions

\footnotetext{
${ }^{64}$ Communication from the Commission, An Initiative to support Work-life Balance for Working Parents and Carers, COM (2017) 252 final, p. 16.

65 "Brexit vote one year on: the EU is more united than ever. Whose loss is it?", The Independent, 22 June 2017, http://www.independent.co.uk/voices/brexit-vote-referendum-one-year-ago-eu-europe-moreunified-theresa-may-loss-ours-a 7803401.html.

${ }^{66}$ See for example the review of the Pregnant Workers Directive.
} 
10. Eurofund: Promoting uptake of parental and paternity leave among fathers in the European Union (2015). Available at: https://www.eurofound.europa.eu/publications/customised-report/2015/ working-conditions-industrial-relations/promoting-uptake-of-parental-and-paternity-leave-amongfathers-in-the-european-union

11. Foubert, P., Imamović, Š.: The pregnant workers directive: must do better: lessons to be learned from Strasbourg? J. Soc. Welf. Fam. Law 37, 309-320 (2015). A special issue on reconciliation of work and family life

12. Fredman, S.: Reversing roles: bringing men into the frame. Int. J. Law Context 10(4), $442-459$ (2014)

13. Horton, R.: Caring for adults in the EU: work-life balance and challenges for EU law. J. Soc. Welf. Fam. Law 37(3), 356-367 (2015). A special issue on reconciliation of work and family life

14. Masselot, A., Caracciolo di Torella, E., Burri, S.: Fighting discrimination on the grounds of pregnancy, maternity and parenthood. The application of EU and national law in practice in 33 European countries. Report to the EU Commission (2012). Available at: http://ec.europa.eu/justice/gender-equality/ files/your_rights/discrimination_pregnancy_maternity_parenthood_final.en.pdf

15. Masselot, A.: The EU childcare strategy in time of austerity. J. Soc. Welf. Fam. Law 37(3), 345-355 (2015). A special issue on reconciliation of work and family life

16. McGlynn, C.: Reclaiming a feminist vision: the reconciliation of paid work and family life in the European Union law and policy. Columbia J. Eur. Law 7, 241-272 (2001)

17. Trimmings, K., Beaumont, P.: General report on surrogacy. In: Trimmings, K., Beaumont, P. (eds.) International Surrogacy Arrangements: Legal Regulation at the International Level. Hart Publishing, Oxford (2013)

18. Zbyszewska, A.: Reshaping EU working-time regulation: towards a more sustainable regime. Eur. Labour Law J. 7(3), 331-347 (2016). A special issue on future directions in EU labour law 